\title{
Serological Relationships of Corynebacteria
}

\author{
By I. LAZAR \\ 'Tr. Savulescu' Institute of Biology, Bucharest, Romania
}

(Accepted for publication 22 November 1967)

\begin{abstract}
SUMMARY
The serological relationships between 39 strains of pathogenic corynebacteria from man, animals and plants were studied by precipitin, double gel-diffusion, and immuno-electrophoretic techniques, with polysaccharides and nucleoproteins as antigens. Five distinct serological groups were established among the plant pathogenic corynebacteria: (I) Corynebacterium flaccumfaciens, C. flaccumfaciens var. aurantiacum, C. poinsettiae and $C$. betae; (2) C. michiganense and C. insidiosum. (3) C. tritici and C. rathayi; (7) C. sepedonicum; and (5) C. facians. C. diphtheriae (type gravis, mitis, intermedius, and atypical forms), C. hoffmanii, (syn. C. pseudodiphtheriticum) and the animal pathogens $C$. equi, $C$. renale and $C$. kutscheri belonged to two or three serological groups. The plant pathogen $C$. fascians appeared to occupy an intermediate position between the plant and animal pathogens, and shared many antigens in common with the plant pathogens in group I and the animal pathogens. Other cross-relationships were detected between the groups. An immuno-electrophoretic study was made of protein fractions from the plant pathogenic bacteria.
\end{abstract}

\section{INTRODUCTION}

Studies of the serological relationships between various species of the genus Corynebacterium are few; most have been concerned with a limited number of species from only a few habitats. Rosenthal \& Cox (1953, I954), in their detailed study of four plant pathogenic species and one species from soil emphasized the desirability of a serological comparison between coryneform bacteria from plant and animals. Mushin, Naylor \& Lahovary (1959) studied some of the Corynebacterium species from plants, animals and man with the object of using serology as a diagnostic tool for the plant pathogens, rather than as a method for investigating their interrelationship and their relation to corynebacteria from other sources. Cummins \& Harris (1956, 1958), Cummins (I962a,b) and Perkins \& Cummins (1964) established relationships between several Corynebacterium species by comparing the antigens and composition of their cell walls. The work of Barber et al. (1963, 1965a, b, 1966) and Saragea, Barber, Meitert \& Maximesco (1963) with Corynebacterium diphtheriae and with some corynebacteria from animals and plants indicated the importance of detailed serological studies in understanding the relations within the group of mammalian pathogens comprising the typical and atypical forms of $C$. diphtheriae, C. hoffmanii (syn. C. pseudodiphtheriticum) and C. xerosis, and revealed some of the serological relationships between these organisms and the animal and plant pathogenic corynebacteria.

Relationships within the corynebacteria have also been demonstrated by other 
methods. Robinson (I966) investigated the esterase, catalase and peroxidase activity, and protein components of several coryneform bacteria by starch-gel electrophoresis, and established a relationship between the human, animal and plant pathogens, which enabled him to divide these organisms into groups and subdivisions. Ramamurthi (1959) made a comparative study of morphological and physiological characters of some coryneform plant pathogens and of single isolates of Corynebacterium creatinovorus, C. equi and C. renale. An Adansonian study of some corynebacteria and related organisms by Harrington (1966), who used a wide range of biochemical and physiological characters, showed that some of the organisms need to be reclassified. Lelliott (I966) pointed out that further morphological, physiological and serological work is needed to confirm his suggestions on the division of plant pathogenic coryneforms and their relation to other corynebacteria.

The work presented in this paper was done with a view to extending the understanding of the serological, and perhaps taxonomic, relationships between coryneform bacteria from plants, animals and man, by means of precipitin, double gel-diffusion and immuno-electrophoretic techniques.

\section{METHODS}

Strains examined. Thirty-nine strains of various Corynebacterium species were used; ten species were from plants, three from animals and three from man. These cultures were obtained from various foreign and local collections (Table I).

Production of antisera. The technique used to obtain antisera with high antibody titres was that described by Barber et al. (1963, 1965a) and Saragea et al. (1963), with slight modifications. Briefly this technique consists of the hyperimmunization of rabbits with cultures in Freund incomplete adjuvant: lanolin, $20 \mathrm{ml}$; paraffin oil, $40 \mathrm{ml}$; bacterial suspension at $\mathrm{I} \cdot 6-2 \cdot 0 \times 10^{9}$ bacteria $/ \mathrm{ml}$., $40 \mathrm{ml}$. For plant pathogenic corynebacteria, living suspensions from $48 \mathrm{hr}$ cultures on agar slopes (corn-steep, $\mathrm{I} \cdot 5 \%(\mathrm{w} / \mathrm{v})$; peptone, $0.5 \%$; glucose, I $\% ; \mathrm{NaCl}, 0.5 \% ; \mathrm{CaCo}_{3}, 0.05 \%$; distilled water, $100 \mathrm{ml}$.) were used, and for animal and human corynebacteria, suspensions of 24-hr cultures on meat broth agar slopes were used. Four ml. of antigen suspension were injected into rabbits $(2 \cdot 8-3 \cdot 0 \mathrm{~kg}$.) subcutaneously into the nape region three times at 2I-day intervals. Twenty-one days after the third inoculation of antigen with Freund adjuvant, five or six intravenous inoculations were given at 6 to 7 -day intervals with nucleoprotein extracts, in increasing doses from $\mathrm{I}$ to $5 \mathrm{mg}$. When the test bleeding did not give a satisfactory precipitin reaction in tubes with homologous polysaccharide, immunization was continued for another two or three intravenous injections.

Production of antigens. Nucleoprotein and polysaccharide antigens were used. They were obtained by extraction of acetone-dried bacteria by the technique described by Barber et al. (1963, 1965a) and Saragea et al. (1963). Cultures were grown on the media described above in Production of antisera. To obtain nucleoprotein extracts, $5 \mathrm{~g}$. of dry bacteria were suspended in $80 \mathrm{ml} .2 \%(\mathrm{w} / \mathrm{v})$ sodium deoxycholate solution for $24 \mathrm{hr}$ at $37^{\circ}$. After centrifugation the supernatant fluid was dialysed for 4-5 days against running tap water, followed by centrifugation of the dialysis residue and dialysis of the supernatant fluid for 2-3 days against distilled water at refrigerator temperature, further centrifugation and finally sterilization by filtration. For polysaccharide extracts, the sediment resulting after treatment with sodium deoxycholate 
solution was resuspended in 50-60 ml. of $0.3 \mathrm{M}-\mathrm{HCl}$ and kept for $45 \mathrm{~min}$. at $90^{\circ}$ in a water bath with continuous stirring. After centrifugation or filtration, the supernatant fluid or filtrate was treated with trichloracetic acid (final concentration $10 \%$. $\mathrm{w} / \mathrm{v})$. The resultant precipitate was removed by filtration and the filtrate dialysed for 3 days in running tap water and for 2 days in distilled water at refrigerator temperature.

Gel diffusion and immuno-electrophoresis. Double gel-diffusion was done by the Ouchterlony technique (1949, I958) and immuno-electrophoresis as shown in detail in another paper (Lazar, 1967), generally by using the techniques described for

Table I. Corynebacterium species studied

$$
\text { Species and culture no. Source Obtained from: }
$$

C. diphtheriae type gravis 4895,5429

C. diphtheriae type mitis $4 \mathrm{II}$

C. diphtheriae P.w.8.

C. diphtheriae type intermedius $1 \mathrm{I} 80$, Man $3522,3536,4109,4465$

C. diphtheriae, atypical form 4409

4528,4852

C. hoffmanii 4855

C. equi $403 \mathrm{I}$

C. renale 2276

C. kutscheri 239

C. betae 373,375

C. flaccumfaciens 559, 567

C. Alaccumfaciens 706

C. f. var. aurantiacum 558

C. poinsettiae 845,848

C. michiganense I

C. michiganense 515

C. michiganense zor

C. michiganense 704

C. insidiosum 83

C. insidiosum 702

C. tritici $255,47 \mathrm{I}$

C. rathayi 797

C. sepedonicum 299

C. sepedonicum 708

C. fascians 156,469

C. fascians 716

'Dr I. Cantacuzino', Institute, Bucarest

* National Collection of Plant Pathogenic Bacteria, Harpenden, Herts, England.

proteins from human serum (Grabar \& Williams, 1953; Grabar \& Burtin, 1960; Heremans, I96I; Bratu, I962). The gel was prepared by dissolving $1 \cdot 2 \%$ of Noble agar (Difco) in veronal buffer (veronal, 2.0766 g.; medinal, 13.4170 g.; sodium acetate, I.2952 g.; potassium oxalate, $0.8346 \mathrm{~g}$; distilled water 21 ; $\mathrm{pH} 8 \cdot 6$ ). The best results were obtained when $13 \times 18 \mathrm{~cm}$. glass plates were covered with $40-45 \mathrm{ml}$. gel. For nucleoprotein migration a series, each of two plates, was introduced into the electrophoresis bath (which contained veronal buffer) at a working potential of about $250-300 \mathrm{~V}$, adjusted to an estimated $\mathrm{I} \cdot 5 \mathrm{~mA} / \mathrm{I} \mathrm{cm}$. of plate. The experiment was carried out in an electrophoresis apparatus of the QE-20I type, manufactured in Hungary. Plates that showed a suitable immuno-electrophoretic reaction were stained with 'Amidoschwarz' solution ( $90 \%$ (v/v) methanol, I0 \% glacial acetic acid, $0.3 \%$ 
'Amidoschwarz' prepared in a water bath for 4-6 hr. After staining, the plates were decolourized with a $2 \%$ acetic acid solution, for one or several days, until the background of the plate was clean. The fractions represented by precipitation arcs along the migration axis were identified by comparison with those reported for fractions in human serum by Grabar \& Williams (1953), Heremans (r96I), Schmid (196I) and, Haggis et al. (1964).

\section{RESULTS}

The results of this study are presented in Tables $2-5$ and partially illustrated in Figs. I and 2.

\section{Tube precipitin reactions}

Tube precipitin reactions (Table 2) indicated that only Corynebacterium fascians, among the plant pathogens, shared more than a limited amount of nucleoprotein antigen with $C$. diphtheriae. Lesser amounts were shared with $C$. diphtheriae by C.poinsettiae, C. flaccumfaciens, C. betae, C. tritici and C. equi, and little or none by $C$. insidiosum, $C$. michiganense, $C$. sepedonicum, $C$. rathayi, $C$. renale and $C$. kutscheri. The species from animals shared common antigens with $C$. diphtheriae, flagellate plant pathogenic corynebacteria and $C$. fascians.

Reactions within the plant pathogenic species suggested five serological groups: (I) C. poinsettiae, C. flaccumfaciens, C. betae; (2) C. insidiosum, C. michiganense; (3) C. tritici, C. rathayi; (4) C. sepedonicum; (5) C. fascians. Small amounts of common antigens were found between some species of these groups (Table 2).

\section{Gel diffusion with nucleoprotein extracts}

The results of the precipitation reaction by double gel-diffusion are shown in Table 3. The reactions between the antisera of the different types of Corynebacterium diphtheriae and the antigens of the phytopathogenic species indicated some relationship, expressed by weak or very weak precipitation lines, between $C$. diphtheriae and the following plant pathogenic species: C.fascians, C. poinsettiae, C. flaccumfaciens, C. flaccumfaciens var. aurantiacum, C. insidiosum, C. michiganense, C. tritici, $C$. rathayi and $C$. sepedonicum.

The antigens of species from animals did not react with the available diphtheriae antisera. However, positive reactions were obtained between the antigens (particularly the nucleoprotein antigens) of Corynebacterium diphtheriae and the antisera of the animal pathogens $C$. renale and $C$. equi.

Antigens of species from plants reacted positively with the antisera of species from animals, the more intense reactions being: Corynebacterium betae, C. flaccumfaciens, $C$. poinsettiae, $C$. fascians and $C$. michiganense with antiserum of $C$. equi; $C$. insidiosum and to a lesser degree $C$. poinsettiae and $C$. flaccumfaciens var. aurantiacum with antiserum of C. kutscheri; C. flaccumfaciens var. aurantiacum, C. flaccumfaciens, $C$. poinsettiae and $C$. fascians with the antiserum of $C$. renale.

The antigenic structural relationship between species from man and from plants was clearer when diphtheria antigens were tested with antisera for plant pathogens than when diphtheria antisera were used against antigens from plant pathogens. This was because in some cases higher-titre antisera were obtained for plant pathogenic species than for species from man. Corynebacterium fascians appeared to be more closely related serologically to the three types of $C$. diphtheriae than were the other 


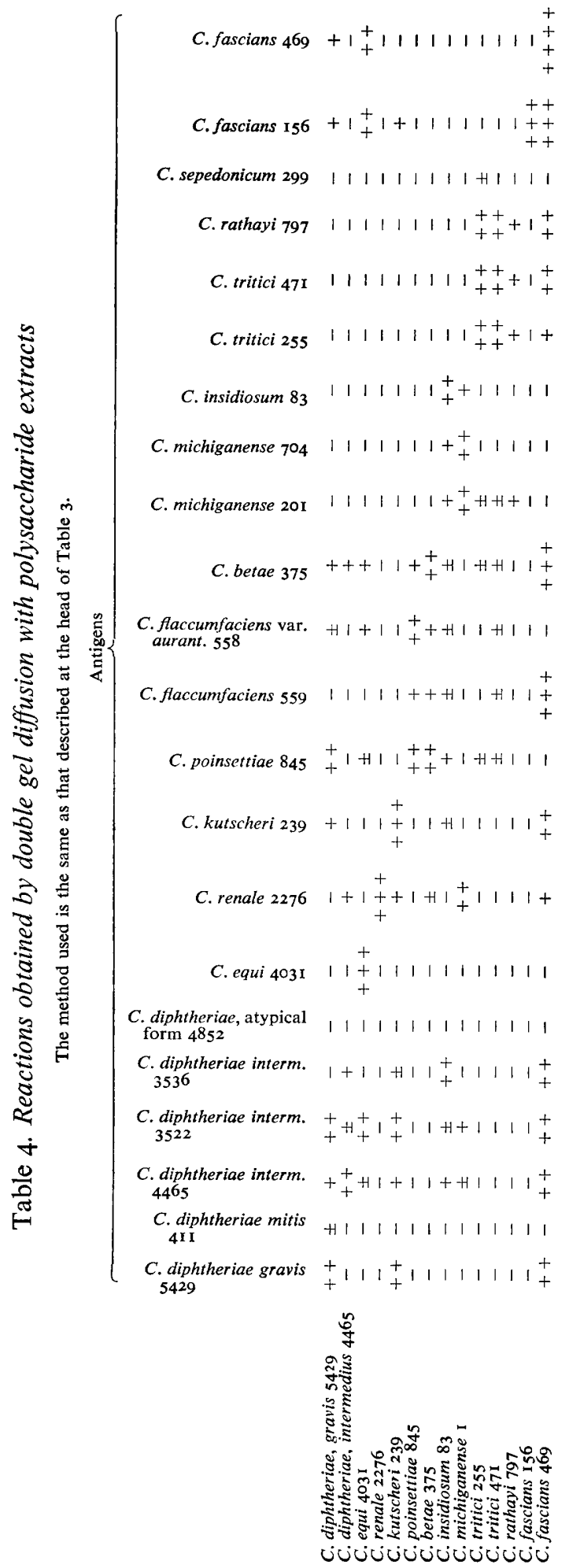


plant pathogens. A positive reaction, though only with the mitis type of $C$. diphtheriae, was obtained with the antisera of the various strains of $C$. michiganense, $C$. insidiosum and $C$. betae. The nucleoprotein antigens of various strains belonging to atypical forms of $C$. diphtheriae also gave one or two precipitation lines with the antisera of C. flaccumfaciens var. aurantiacum and $C$.poinsettiae, and one single and weak precipitation line with the antiserum of $C$. michiganense 704; a very weak or doubtful reaction was obtained with $C$. michiganense $\mathrm{I}$ and $5 \mathrm{I} 5$.

Some antisera of the plant pathogenic species formed a clear precipitation line with some antigens of different species from animals: Corynebacterium insidiosum with C. equi and C. kutscheri, C. fascians 469 with C. kutscheri; C. sepedonicum 299, and less clearly $C$. michiganense 704 , with $C$. renale.

The same five groups within the plant pathogenic corynebacteria were distinguished by gel diffusion as were demonstrable by tube precipitin reactions (see above).

\section{Gel diffusion with polysaccharide extracts}

The results of double gel diffusion with polysaccharide antigens are given in Table 4. The weaker relationships between groups were less clear than with nucleoprotein extracts. Thus the antisera of Corynebacterium flaccumfaciens 599, C. flaccumfaciens var. aurantiacum 558, C. poinsettiae 848, C. sepedonicum 299, C. michiganense $705, C$. diphtheriae type mitis $4 \mathrm{I}$ I, as well as a few others, gave no satisfactory reactions with homologous antigens, probably because these strains produced little polysaccharide or because what polysaccharide they did produce was serologically inactive. Generally the relationships demonstrated were the same as those with nucleoprotein extracts. Antisera of $C$. diphtheriae gave usually weak reactions with the antigens of one or more strains of C. renale, C. kutscheri, C. poinsettiae, C. flaccumfaciens var. aurantiacum, $C$. betae and $C$.fascians. Some of the antisera against species from animals reacted with antigens of one or more strains of $C$. diphtheriae type intermedius, C. fascians, C. betae, and C. flaccumfaciens var. aurantiacum. The antisera of plant pathogens reacted with some of the antigen preparations of $C$. diphtheriae type intermedius, $C$. diphtheriae type gravis, C. renale and C.kutscheri. The reactions between the polysaccharide antigens and the antisera of plant pathogenic species reinforced the serological groups of species determined by the reaction with nucleoprotein antigens (see above).

The interrelationships schematized in Fig. 2 show that plant pathogenic corynebacteria of groups I, 2 and 5 share more polysaccharide antigens with the human and animal corynebacteria than do groups 3 and 4 . Corynebacterium fascians (strain 469 ) is very rich in polysaccharide antibodies, as well as in nucleoprotein antibodies (Tables 3,4 ) and shows a particularly clear relationship with the corynebacteria from man and animals and also with the other groups of plant pathogenic corynebacteria.

\section{Immuno-electrophoresis}

The results obtained by double gel diffusion were confirmed by immuno-electrophoresis. It was also possible by using immuno-electrophoretic techniques to identify and make a more exact estimation of the number of antigenic fractions.

Antisera with high antibody titres, and the application for migration of about $0.2 \mathrm{ml}$. of not less than $\mathrm{I} \cdot 5-2 \cdot 0 \mathrm{mg}$. nucleoprotein antigen $/ \mathrm{ml}$., were necessary to 


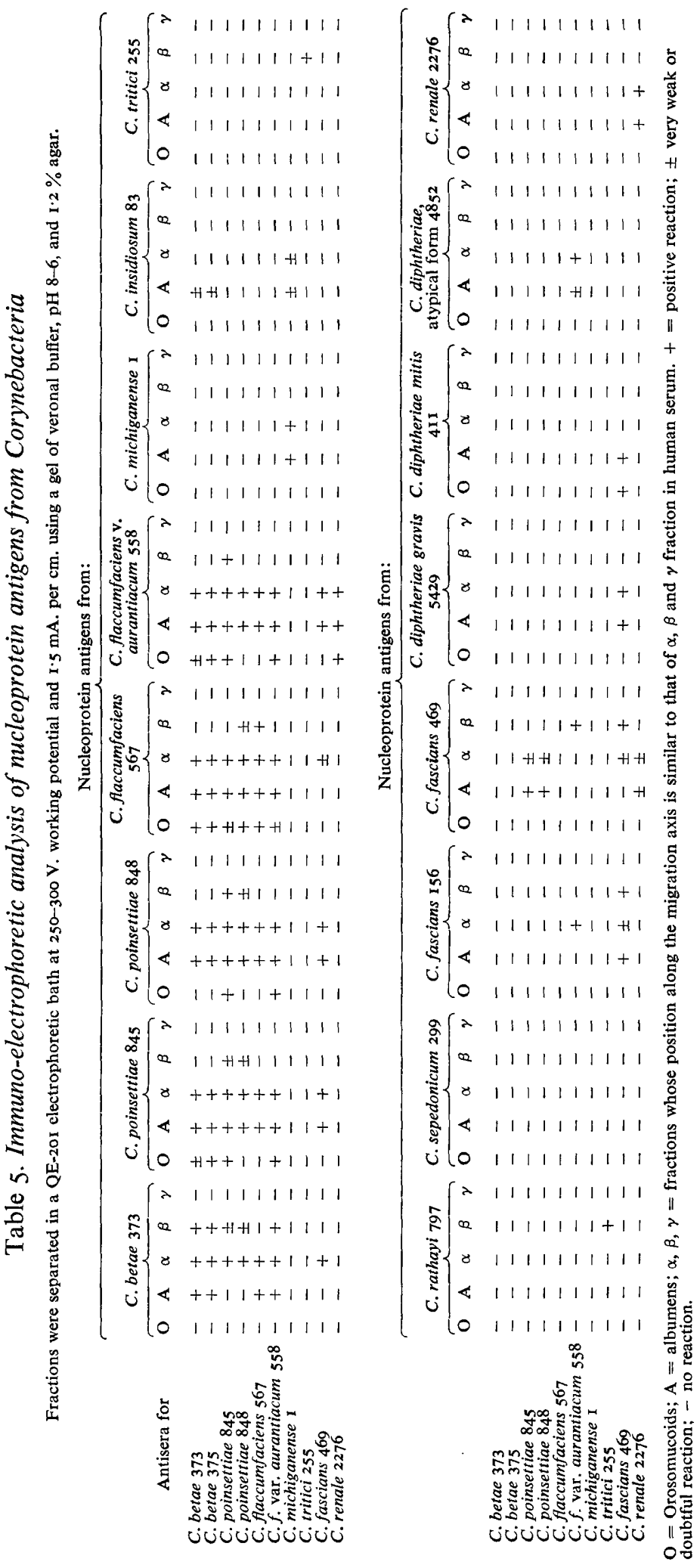


detect and identify some of the antigens detectable by gel diffusion. These conditions were not realized with some of the nucleoprotein extracts, including those of Corynebacterium sepedonicum 299, C. flaccumfaciens 559, C. insidiosum 83, C. rathayi 797 C. kutscheri, C. diphtheriae (some types), etc., and some antisera, including those of C. insidiosum, C. sepedonicum, C. fascians (some strains), C. kutscheri, C. equi. For this reason some of the antigens and antisera tested are not included in Table 5.

The electrophoretic migration of the nucleoproteins was towards the positive pole and their deposition was in zones comparable to those of the orosomucoids, albumins, and group $\alpha$ and $\beta$ fractions from human serum. In runs in which the nucleoprotein extracts of the different Corynebacterium species were compared with human serum, fractions with the same mobility as the $\alpha$ group and the albumins were detected most frequently; fractions comparable with the orosomucoids, and with group $\beta$ less frequently. No fractions comparable to group $\gamma$ were detected.

The species richest $\left(5^{-8}\right)$ in fractions identifiable with the proteins from human serum were: Corynebacterium flaccumfaciens var. aurantiacum 558, C. poinsettiae 845 , 848, C. flaccumfaciens 567, 706, C. betae 373, 375, C. fascians 469, 156, and C. michiganense I. A few comparable fractions (2-3) were identified in: C. tritici $255, C$. rathayi 797, C. fascians 716, C. diphtheriae 5429, 4I I, 4465, 4528, C. renale 2276 and $C$. kutscheri 239. It is possible that, using more concentrated nucleoprotein antigens and antisera richer in antibodies, these strains and those of others including $C$. sepedonicum C. insidiosum and C. equi, could be shown to have more protein fractions in the nucleoprotein antigens extractable from bacterial cells with sodium deoxycholate.

In addition to confirming the groups obtained by tube precipitin and gel-diffusion techniques, immuno-electrophoresis confirmed that group I was very rich in antigenic fractions and group 3 poor. It also indicated closer relationship between Corynebacterium flaccumfaciens var. aurantiacum and $C$. poinsettiae than between $C$. flaccumfaciens var. aurantiacum and C. flaccumfaciens. C. flaccumfaciens var. aurantiacum and $C$. poinsettiae have fractions identical in number and in their electrophoretic position.

Plant pathogenic corynebacteria from groups I, 5 and 3 appear to be related to human and animal coryneforms in albumens and fractions from group $\alpha$ and possibly in fractions from group $\beta$.

\section{DISCUSSION}

By means of the classical methods and criteria used for differentiating diphtheroids, Lazar (I968) has shown that most of the plant pathogenic corynebacteria resemble the pseudodiphtheria organisms from man and animals in many of their characters. Corynebacterium fascians presented a striking resemblance to $C$.diphtheriae and particularly to its atypical forms; this is not in agreement with the suggestion that C. fascians should be classified as a member of the genus Nocardia (Ramamurthi, I959) or that it is a boundary form between the genera Corynebacterium, Mycobacterium and Nocardia (Lacey, 1955).

The present serological study of a wide range of coryneform bacteria by precipitationdouble gel-diffusion, and immuno-electrophoresis techniques has confirmed and amplified previous results obtained with agglutinins, cell extracts and cell-wall, composition (Mushin et al. 1959; Cummins, I962a, b; Cummins \& Harris, 1956, 1958; Perkins \& Cummins, 1964; Barber et al. 1965 b, 1966), and has indicated the 
broad relationships demonstrated in Figs. I and 2. It appears that plant pathogenic coryneforms can be placed in five distinct serological groups: (I) Corynebacterium flaccumfaciens, C. flaccumfaciens var. aurantiacum, C. poinsettiae, C. betae; (2) C. michiganense and C. insidiosum; (3) C. tritici and C. rathayi; (4) C. sepedonicum; (5) C. fascians.

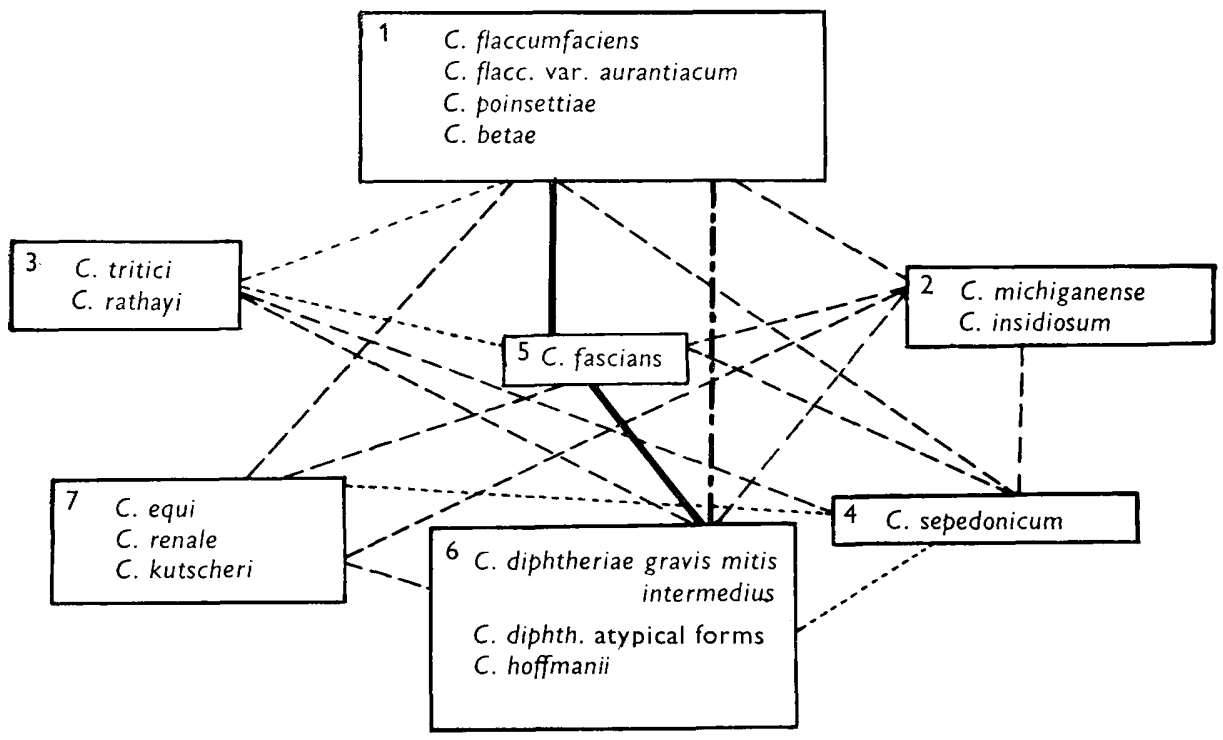

Fig. I. Serological relationships as determined by double gel diffusion and immunoelectrophoresis techniques, using nucleoprotein extracts as antigen. __ reaction; - - -, weak reaction; ......, very weak or doubtful reaction.

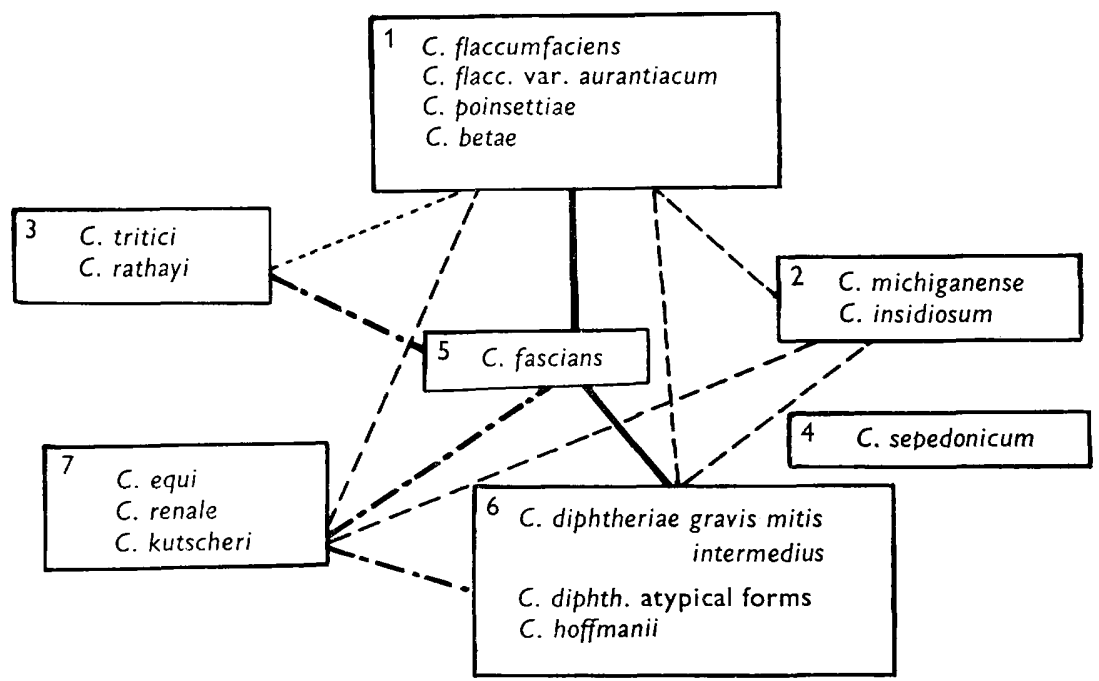

Fig. 2. Serological relationships as determined by double gel diffusion method, using polysaccharide extracts as antigen. __- Strong reaction; _-_, reaction; ---, weak reaction; ......, very weak or doubtful reaction. 
The results have confirmed the work of Rosenthal \& Cox (1953, 1954) who, by cross-absorption, showed serological identity between the Corynebacterium michiganense and the $C$. insidiosum AB serotypes, and the very close serological relationship of $C$. poinsettiae with $C$. flaccumfaciens. The results also confirm the finding by Katznelson \& Sutton (1956) that $C$. sepedonicum shares one or more antigens with $C$. michiganense and $C$. flaccumfacens, but also show that $C$. sepedonicum shares antigens with $C$.poinsettiae, $C$. fascians, $C$. betae and $C$. rathayi. The results also confirm the division of the plant pathogenic coryneform bacteria suggested by Lelliott (1966), but show that his first group contains three serological groups, and his second group two serological groups.

Corynebacterium species from plants, animals and man are antigenically related (Figs. I, 2). Corynebacterium fascians and the species in the C. flaccumfaciens group (group I) are the plant pathogens most closely related to corynebacteria from man and animals. Corynebacterium fascians appears to be most closely related to C. diphtheriae, and species in group I to the atypical forms of $C$. diphtheriae. Corynebacterium fascians appears to occupy a central position, showing very close affinity with the human and animal corynebacteria, and also with the flagellated group $\mathrm{x}$. Other approaches to the problem have also indicated this intermediate or central position of $C$. fascians. Robinson (1966) showed that $C$. fascians produced a pattern of enzymes similar to that produced by some plant, some human and some animal pathogenic corynebacteria. Its peroxidase pattern was similar to that of the plant pathogens but its esterase and catalase pattern was like that of the animal pathogens. Robinson also found that $C$. tritici had an enzyme pattern which showed very little relationship with the other plant pathogens; a similar lack of relationship in nucleoprotein antigens between $C$. tritici and $C$. rathayi and the other plant pathogenic corynebacteria is shown in Fig. I. An Adansonian taxonomic study (Harrington, 1966) has also indicated that $C$. fascians appears to be the plant pathogen most closely related to the animal strains.

Barber et al. (1963, 1965a) and Saragea et al. (1963) showed that Corynebacterium diphtheriae and the other Corynebacterium species from man are related to each other only through their nucleoprotein antigens, and that their polysaccharide antigens are specific. They also showed a serological specificity for the polysaccharides isolated from different plant pathogenic corynebacteria (Barber et al. 1966). The results. reported here, however, show that the polysaccharide antigens of several Corynebacterium species from plants $C$. fascians 469,156 ; C. betae 375 ; C. poinsettiae 845 ; $C$. flaccumfaciens var. aurantiacum 558) react with $C$. diphtheriae antisera and, even more clearly, that the polysaccharides of $C$. diphtheriae react with the antisera of C. fascians 469, C. insidiosum 83, C. kutscheri 239 and C. equi 403I. Other examples of common polysaccharide antigens are given in Table 4 .

The serological relationship found between certain species from plants and Corynebacterium diphtheriae (including its atypical forms) seems to be at least as close as that ascertained by Barber et al. (1963, 1965a) and Saragea et al. (1963) between $C$ diphtheriae on the one hand, and the atypical forms and $C$. hoffmanii and $C$. xerosis on the other. It appears justifiable to consider that, if the place of pseudodiphtheroids and atypical forms within the genus Corynebacterium cannot be doubted, then neither can that of the diphtheroids from plants among which $C$. fascians is included. As Gorlenko (1964) suggested, C. fascians may be an intermediary form in this group of 
bacteria. To understand more clearly the interrelationships of corynebacteria, it will be necessary to study the relationship of members of the genus Corynebacterium, particularly $C$. fascians and $C$. renale, with representative species of the genera Arthrobacter and Nocardia.

My gratitude is due to Mr R. A. Lelliott, Plant Pathology Laboratory, Harpenden, for his critical review of this paper and for useful suggestions for improving its content.

\section{REFERENCES}

Barber, C., Lazar, I. \& Meitert, E. (1966). Contributions à l'étude des relations entre corynébactéries diphthériques et corynébactéries phytopathogènes. La spécificité sérologique des polysaccharides isolés des corynébactéries phytopathogènes. Pathologia Microbiol. 29, 84 .

Barber, C., Mertert, E. \& Saragea, A. (I965a). Contributions à l'étude des antigènes endobactériens isolés des bacilles diphthériques. La specificité des polysaccharides pour l'espèce $C$. diphtheriae; antigèns à specifité de type. Pathologia Microbiol. 27, 274.

Barber, C., Meitert, E., Saragea, A., Bica Popit, V. \& Lazar, I. (1965b). Contribution à l'étude immunochimique des Corynébactéries. Archs roum. Path. exp. Microbiol. 24, 727.

Barber, C., Calalb, G., Meitert, E., Saragea, A., Stanica, E. \& Stoian, C. (1963). Contribution à l'étude des antigènes endobactériens isolés des Bacilles diphtheriques. I. Relations entre les antigènes endobactériens, les serums antibactériens et l'antitoxine diphthériques. Archs roum. Path. exp. Microbiol. 22, 357.

Bratu, V. (I962). Imunoelectroforeza. Documentare de Hematologie și transfuzie. Minist. Sănăt. Preved. Sociale. Centrul de Hematologie. București. 5, 155.

Cummrns, C. S. (I962a). Immunochemical specificity and the location of antigens in the bacterial cell. Symp. Soc. gen. Microbiol. 12, 212.

Cummins, C. S. $(1962 b)$. Chemical composition and antigenic structure of the cell walls of Corynebacterium, Mycobacterium, Nocardia, Actinomyces and Arthrobacter. J. gen. Microbiol. 28, 35.

Cummins, C. S. \& Harris, H. (1956). The chemical composition of the cell in some Gram-positive bacteria and its possible value as a taxonomic character. J. gen. Microbiol. 14, 583 .

Cummins, C. S. \& HarRis, H. (1958). Studies on cell-wall composition and taxonomy of Actinomyces and related groups. J. gen. Microbiol. 18, 173.

Gorlenko, M. V. (1964). Proiskhoshdenye i evolutsia parazitisma fitopatoghenii bakterii. Abstr. Host-Parasite Relations in Plant Pathology, p. 4. Symposium of Hungarian Academy of Science.

Grabar, P. \& Burtin, P. (1960). Analyse Immune-Electrophorétique. Applications aux Lignides Biologiques Humains. Paris: Masson.

Grabar, P. \& Williams, C. A. (1953). Méthode permetant l'étude conjugée des propriétés electrophorétiques immunochimiques d'une mélange des protéines. Application au serum sanguin. Biochim. biophys. Acta 10, 193.

Haggis, G. H., Michie, D., MuIR, A. R., Roberts, K. B. \& Walker, P. E. M. (I964). Introduction to Molecular Biology. p, 25. Bristol: Western Printing Services Ltd.

HaRrington, J. B. (1966). A numerical taxonomical study of some Corynebacteria and related organisms. J. gen. Microbiol, 45, 3 I.

Heremans, I. (1961). Les Globulines Sériques du Système Gamma. Leur Nature et Leur Pathologie. Bruxelles and Paris: Editions Arscia S.A.

Katznelson, H. \& Sutton, M. D. (1956). Laboratory detection of Corynebacterium sepedonicum, causal agent of bacterial ring rot of potatoes. Can.J. Bot. 34, 48.

LACEY, M. S. (1955). The cytology and relationships of Corynebacterium fascians. Trans. Br. mycol. Soc. $38,49$.

LAZAR, I. (1967). The immunoelectrophoresis of nucleoproteic antigens of the various species of genus Corynebacterium. Symposium on Methods in Soil Biology, I965, p. 89, Bucharest: The Roumanian National Society of Soil Science.

LAZAR, I. (1968). Comparative morphological, cultural and biochemical investigations between species of Corynebacterium from plants, animals and man. Rev. roum. Biol., Sér. Bot. 13, No. 3. 
LeLliotT, R. A. (1966). The plant pathogenic coryneform bacteria. J. appl. Bact. 29, I I4.

Muschin, R., NAYLOR, J. \& LAHOVARY, N. (1959). Studies on plant pathogenic bacteria. II. Serology. Aust. J. biol. Sci., 12, 232.

OUCHTERLONY, O. (1949). Antigen-antibody reaction in gels. Acta path. microbiol. scand. $26,507$.

OUCHTERLONY, O. (1958). Diffusion in gel, methods for analysis of precipitating immune-systems of high complexity. Recent Progress in Microbiology, 7 th int. Congr. Microbiol. p. 163.

Perkins, H. R. \& Cummins, C. S. (1964). Chemical structure of bacterial cell walls. Nature, Lond. 20I, I IO5.

RamamurThi, C. S. (1959). Comparative studies on some Gram-positive phytopathogenic bacteria and their relationship to the Corynebacteria. Mem. Cornell Univ. agric. Exp. Stn no. 366.

RoBinson, K. (1966). An examination of Corynebacterium spp. by gel electrophoresis. J. appl. Bact. 29, 179.

Rosenthal, S. A. \& Cox, C. D. (1933). The somatic antigens of Corynebacterium michiganense and Corynebacterium insidiosum. J. Bact. 65, 532.

Rosenthal, S. A. \& Cox, C. D. (1954). An antigenic analysis of some plant and soil corynebacteria. Phytopathology 44, 603 .

Saragea, A., Barber, C., Meitert, E. \& Maximesco, P. (1963). Contribution à l'étude des antigèns endobactériens isolés de bacillus diphthérique. II. Relations sérologiques entre les Corynebactéries atypiques et l'espèce type Corynebacterium diphtheriae. Archs roum. Path. exp. Microbiol. 22, 369.

Schmid, K. (196I). In Analyse Immunoelectrophorétique, chap. 23. Ed. by P. Grabar \& P. Burtin. Paris: Masson. 